\title{
Obstacles and challenges for implementing a geographical indication: the case of rennet cheese from jaguaribe-CE
}

\begin{abstract}
The process of implementing a Geographical Indication is slow and complex and requires an institutional arrangement formed by several institutions, which is efficient in the articulation of all actors involved and the decentralization of information, reaching/covering more than the institutions and technicians who are effectively involved in creation process. The state of Ceará has great potential to implement the Geographical Indication, as it presents differentiated products in some regions, such as rennet cheese, whose production chain is responsible for generating employment and income in the municipality of Jaguaribe. However, the GI recognition process for this product has not advanced, despite the efforts of the local agents involved. In this sense, this work aims to analyze the implementation process of the Geographical Indication of rennet cheese from Jaguaribe-CE, to determine the role of the agents involved, the obstacles and the challenges that prevent the progress of its implementation. A research of a descriptive and exploratory nature was carried out, with a qualitative approach, of the type of case study, mediated by documentary research and semi-structured interview with agents involved in the process. The results were several obstacles, among them the lack of legislation, the high cost of implementation and the lack of financing, in addition to a greater articulation of the producers and agents involved. A research of a descriptive and exploratory nature was carried out, with a qualitative approach, of the type of case study, mediated by documentary research and semi-structured interview with agents involved in the process. The results were several obstacles, among them the lack of legislation, the high cost of implementation and the lack of financing, in addition to a greater articulation of the producers and agents involved. A research of a descriptive and exploratory nature was carried out, with a qualitative approach, of the type of case study, mediated by documentary research and semi-structured interview with agents involved in the process. The results were several obstacles, among them the lack of legislation, the high cost of implementation and the lack of financing, in addition to a greater articulation of the producers and agents involved.
\end{abstract}

Keywords: geographical indication, rennet cheese, jaguaribe, ceará, obstacles, challenges, implantation
Volume 5 Issue I - 202 I

\author{
Elda Fontinele Tahim \\ Profa. the CENTEC Institute and the Graduate Program in \\ Business Administration at UECE, Brazil
}

Correspondence: Elda Fontinele Tahim, Profa. the CENTEC Institute and the Graduate Program in Business Administration at UECE, Brazil, Email fontineletahim@gmail.com

Received: March 04, 202I | Published: March 17, 202 I
Abbreviations: IGs, geographical indications; DO, denomination of origin; INPI, national institute of industrial property; IP, indication of origin; SEBRAE, service brazilian support for micro and small enterprises; WTO, world trade organization; WIPO, world intellectual property organization

\section{Introduction}

Geographical Indications (IGs) in Brazil are provided for by the Industrial Property Law (Law No. 9,279, of May 14, 1996) and are seen as instruments for mobilizing and valuing territories and adding value to typical products of differentiated quality, in addition to being legal tools for intellectual protection used to identify the origin of products or services, when the location becomes known, or when a certain characteristic or quality of the product or service is due to its geographical origin. The geographical delimitation of the area of a GI must be supported by technical arguments, always taking into account the historical-cultural survey, the natural, political and economic factors. The IG is the one that will express the social relations of production, transformation and elaboration of the product. ${ }^{1,2}$ Therefore, it is an instrument that makes it possible to value traditions, customs, knowledge, practices and other immaterial goods associated with immaterial identity. They can still be considered as potential instruments for territorial development, given that they allow the exploitation of intangible assets, difficult to transpose into other territories. ${ }^{2-6}$ In Brazil, the body responsible for registering Geographical Indications is the National Institute of Industrial Property (INPI) and there are two types of Brazilian Geographical Indications: the Indication of Origin (IP) and the Denomination of Origin (DO), which have been affirming on the national scene in the search for competitiveness in its various aspects, such as: quality, protection, reputation, conscious consumption, not only economic, but also socio-environmental improvement, among others.

Brazil has immense potential for the identification of sociobiodiversity products and products from traditional contexts, as the national cultural and productive diversity is notorious with great possibilities in terms of business, especially those with differentiated qualities resulting from cultural characteristics and technical, geographic aspects. and climatic, which may have a strong relationship with their geographic origin. ${ }^{7,8}$ In the Northeast of Brazil, despite its diversity of local production, composed mainly of traditional products, the GI record is still insignificant. In Ceará, only one IG certified with Denomination of Origin (Shrimp from the Black Coast) was registered, However, the process of implementing recognition of these potential Geographical Indications is unable to advance, even 
with the involvement of some public and private agents such as the Brazilian Agricultural Research Corporation (Embrapa), the National Institute of Industrial Property (INPI), the Service Brazilian Support for Micro and Small Enterprises (Sebrae) and the association of local producers. For Oliveira et al. ${ }^{9}$, ensuring the recognition of the origin and quality of regional products is one of the main ways to ensure their protection, and thus to preserve the reproduction of productive processes of "know-how", contributing to the economic sustainability of the activity of producers involved.

On the other hand, in an environment of increasing competition, especially in the agrifood sector, in which the large global chains predominate, the presence of small producers will only be made possible with the differentiation of their products and the diversification of their sales channels. In this context, Geographical Indications become one of the potential sources of competitive advantages for small producers. ${ }^{10,11}$ Mascarenhas et al. ${ }^{5}$ emphasize that, However, the process of implementing a GI requires institutional and productive arrangements "permeated by a type of governance inherent in the region in which it is located". ${ }^{12}$ Furthermore, it is not a linear process, but a complex one, as it encompasses multiple activities that demand the orderly performance of multi and interdisciplinary agents, involving specific public policies, support from research institutions, sharing of experiences and collective learning from the public and private sectors. among other aspects. ${ }^{13-15}$ Given this perspective, the following question arises: Why does the implementation of GI fail to advance, even though the potential of the place is known? To answer this question, the process of implantation of the handmade Coalho Cheese GI from the Jaguaribe region, Ceará, will be taken as a basis. The main objective of the research was to analyze the implementation process of the Geographical Indication of Coalho Cheese from Jaguaribe-CE, pointing out the role of the agents involved, the main obstacles and challenges that prevent the progress towards its implementation.

\section{Geographical indications and their importance}

Geographical Indications are innovative strategies that constitute special forms of protection for products, aiming, mainly, to distinguish the origin of a product through the identification of its production area. With the globalization of the economy, Geographical Indications make it possible to preserve the local and regional characteristics of products, valuing and attesting to their levels of quality, which may be the result of natural factors in a given area and/or factors arising from human intervention. ${ }^{16}$ According to Caldas ${ }^{17}$ the Geographical Indication (GI) is a type of Intellectual Property used to identify the origin of products or services when the place has become known (Indication of Origin) or when a specific characteristic or quality of the product or service is due to its origin (Indication of Origin). The author also clarifies that the IGs are regulated by international organizations such as the World Trade Organization (WTO) and the World Intellectual Property Organization (WIPO) and in Brazil by the National Institute of Industrial Property (INPI). However, for a seal to function as a GI, the national legislation of each member country must contain the relevant provisions. Geographical Indications can be applied to a wide variety of products, with emphasis on agricultural products. The concept of Geographical Indications, an area of intellectual property law widely discussed and applied in regions of Europe and the United States, disseminated in Brazil only in the 2000 s, applies to products with a well-defined geographic origin. ${ }^{18,19}$ Therefore, in Brazil, the notion of Geographical Indication (GI) emerged gradually, when producers and consumers began to realize that some products from certain locations had peculiar flavors or qualities, neither better nor worse, but typical, differentiated, never found in equivalent products made elsewhere..$^{20}$ It is well known that the use of Geographical Indications as a tool for local development is the subject of many studies in the literature that include discussions about its economic, social, cultural and environmental effects. ${ }^{2,6,21}$ The concept of Geographical Indication has been consolidated over the years as an instrument for the protection and enhancement of local products.

Many studies emphasize the role of GIs as a collective instrument for the appropriation of immaterial goods, for the protection and commercial promotion of traditional products, considering them as a way of using local comparative advantages to boost the development of regions and localities. ${ }^{2}$ As described by the International Trade Center (ITC, 2009), there are benefits arising from the recognition of Geographical Indications, with regard to local development, increased employment and improved quality of life, especially in the rural environment. GIs provide products with the necessary structure to preserve the cultural, traditional and environmental values that characterize them. According to Mascarenhas et al. ${ }^{5}$ the GIs can serve as useful structures to promote an integrated form of rural development, which can facilitate the equal participation of all members.Although the specialized literature demonstrates that GIs can contribute to strengthening economically fragile or underdeveloped regions, there are still suspicions regarding their efficiency. Froehlich et al. ${ }^{22}$ point out that there is strong mistrust on the part of significant sectors and actors linked to family farming about the capacity of the IGs to promote development, visualizing in them an inherently exclusive character, aimed at favoring already privileged socioeconomic groups (agribusiness), due to the type of market they allow to access and the conditions for obtaining it. However, for the process of implementing a GI to take place effectively, it is necessary to consolidate a network of actors acting in an integrated and structured way.

\section{The process of implementing a GI}

For the implementation of a GI, collective action involving several agents is necessary, since it is a non-linear process, resulting from the overlapping of several activities that require the performance of multiple and interdisciplinary agents such as: specific public policies, support from research institutions, sharing of experiences and collective learning from the public and private sectors, among others, as highlighted by Velloso (2008). The process of institutionalization of a IG, which includes, among other initiatives, the formalization of the rules that make up the Use Regulation, is one of the ways to guarantee the quality and consolidate the identity of the IG, as well as to make it possible for it to be recognized by the market., strengthening local producers. In addition, the process of implementing and regulating a Geographical Indication is long and expensive and the definition of the usage regulation is a complex issue, since each established rule implies a risk of exclusion, either due to geographic requirements or technical requirements, which may lead to additional costs and investments for producers. ${ }^{7,15,23}$ According to $\mathrm{Tahim}^{2}$ the definition of the rules on the conditions for obtaining the particular characteristics of the product for the purpose of implanting a GI occurs through a control body. These standards are a key step in the implementation of a GI. They must be clearly described and controlled, consisting of the result of the decision-making process between members of the productive chain and must still follow the Normative Instruction No. 25/2013 establishes the conditions for the Registration of Geographical Indications. ${ }^{24}$ The regulation for the use of an IG refers to a series of rules defined and agreed upon between producers within the area defined by the IG, which must be followed so that they can use the IG seal on their products. The extension of the coverage area must define, with great precision, the territory 
where the original product is produced. ${ }^{4}$ According to the $\mathrm{INPI}^{24}$ for the process of obtaining a GI it is necessary to create a control structure over producers or service providers that have the right to the exclusive use of the Geographical Indication seal in their products. and / or services. This control is essential and has the responsibility to determine which producers met the criteria adopted for the implementation of the IG, leaving those who do not comply with them out of the process. However, Santos ${ }^{25}$ state that models of this nature tend to select groups that are more technically and economically able, to the detriment of those that are unable to adapt to such criteria and standards. The granting of a Geographical Indication also requires an entity with collective representation to bring together producers in the territory. Thus, the group of producers must be formalized through an association or cooperative, which, for Santos ${ }^{25}$ might be interesting to synthesize the organizational processes of a territory, even favoring the improvement of existing processes to be used as vectors of the creation of Geographical Indications. On this aspect, Silva et al. ${ }^{26}$ affirm that the definitive approval of the registration of IP or DO can take months or years and, in general, this process must be conducted by a promoting association (of producers and/or creators), which must establish the norms to followed by all producers.

\section{Main obstacles and challenges to the process of institutionalization/implantation of geographical indications in Brazil}

Several studies have shown innumerable difficulties and obstacles to the implantation of a GI, reflecting the weaknesses of the current institutional and organizational arrangement in Brazil. 5,14,19,21,27,28 The issues pointed out by these authors to be overcome in the process of implementing a GI are both practical and technical. Silva et al. ${ }^{27}$ cite at least three issues that can create obstacles to the institutionalization of Geographical Indications in Brazil. The authors also make a comparison between the criteria used in Brazil and in the European Union for the granting of Geographical Indications and point out the most significant differences. The second obstacle is related to the fulfillment of what is set out in the rules of use or regulation of use or in the production certification system. In the European Union, government entities play a fundamental role in this process, including certifying their own private certifiers. In Brazil, it is necessary to consolidate a certification system that specifically values agri-food production and articles with differentiated quality. ${ }^{27}$ Finally, the authors highlight the fragility of Brazil's Geographical Indications system when compared to that of the European Union, since $50 \%$ of the expenses of the EU Regulatory Councils, related to the promotion and dissemination of their products, are borne by economic subsidies from the EU itself .Research carried out by Niederle ${ }^{29}$ in the Vale dos Vinhedos region, in Rio Grande do Sul, shows that the processes of Geographical Indication in Brazil are in "quicksand", given the many inaccuracies and vagueness regarding the the role of the institutions involved in the processes, since there are no consolidated rules on the title of the certificate and the requirements to compose the dossier and the relevant forms of control, leading producers to constantly readjust "to new rules as they arise for address the deficiencies of the legal framework in force".

Another difficulty encountered until obtaining the recognition of the Geographical Indication was the accomplishment of a work to convince the producers, instilling in them the idea that the Geographical Indication could be an interesting instrument for the local development of the region, for the wine sector of the Valley, as it adds a differential to the products produced in the region. ${ }^{30}$ Pellin $^{31}$ affirm that the main challenges for the implementation of Geographical Indications are in the structuring of an efficient institutional arrangement in the articulation of all the actors involved; the high financial cost for implementing and maintaining a GI; and the danger of the commercialization of production processes, which puts at risk the typicality of the products linked to their origin. According to Niederle ${ }^{29}$ this risk is associated with the readjustment of GIs in order to catalyze technical and organizational innovations, threatening traditional production methods. Another weakness in the process of maintaining Geographical Indications is in the post-registration management mechanisms. After a time of creation of the IG, in several regions it has been observed that producers begin to question the promised socio-economic "impacts" of obtaining the IG and, in some cases, even failing to use it due to the lack of compensatory monetary return from the costs of adapting to norms and standards. ${ }^{21}$ In other situations, there has not even been a conformity assessment and producers never use the IG seal on their products. This is the case of the Camarão da Costa Negra IG submitted by the Association of Shrimp Farmers of the Costa Negra (ACCN) of Acaraú-CE, which was recognized on $08 / 16 / 2011$ by the INPI, however, the producers did not carry out the conformation of the process of production, such as the implementation of product traceability, among others. There are still several problems in relation to the management of ACCN, such as the absence of a meeting of the Regulatory Council, the low participation of members and the lack of financing, among other obstacles. ${ }^{20}$

Santos ${ }^{32}$ in order to better understand the processes that involved the IG Queijo Minas Artesanal / Serro (QMA / Serro) before its implementation, sought to directly grasp the perception of the process of implementing the Geographical Indication (IG) and the expectations about the producers. of its implementation as an instrument of valorization of the QMA / Serro. Immediately, the author realized that they did not have much information about it and that questions about the topic ended up embarrassing them, as they "did not know how to answer", a situation considered by the author to be one of the greatest challenges, perhaps one of the greatest obstacles to the process of implantation of Brazilian IGs.During the fieldwork for the implementation of the IG of the QMA / Serro, Santos ${ }^{32}$ observed that the IG theme was not widespread in the region and that it would not be easy to find people who mastered and understood this theme since it was not popularized among the interlocutors. This was later verified and understandable, given that the information was centralized in institutions and technicians who were effectively involved in the implementation of the process. In this context, according to the author, knowing the paths that led to the implantation of the Minas Gerais / Serro Cheese Geographical Indication was an arduous task. Vieira et al..$^{33}$ and Valente et al. ${ }^{34}$ point out that the lack of knowledge of consumers in relation to IGs, not contributing to the appreciation of this differential in the national market, is a factor that directly affects the interest of producers in obtaining certifications, together with the difficulties in preparing the entire process. Another difficulty concerns the post-registration management of GI, that is, it is the use of control mechanisms to prevent fraud, adulteration and misuse of the name GI, which has become an object of recognition, but which can put at risk the reputation of the producing region and the product with consumers.

In Brazil, production control can occur in three ways: internal control - required by Normative Instruction No. 25/2013 of INPI ${ }^{24}$ carried out by regulatory councils formed by producers, technicians and sector representatives; self-control - exercised by the producers themselves who control productive practices; and external control which implies the performance of audits by a body that is not directly 
involved with the management of the IG under evaluation. However, Brazilian law practically does not provide for the use of external control mechanisms, whereas in the European Union, governmental entities play a fundamental role in this process, carrying out audits and certifying the private certifiers themselves. ${ }^{25,26,31}$ And external control - which implies the performance of audits by a body that is not directly involved with the management of the IG under evaluation. However, Brazilian law practically does not provide for the use of external control mechanisms, whereas in the European Union, governmental entities play a fundamental role in this process, carrying out audits and certifying the private certifiers themselves. ${ }^{25,26,31}$ And external control - which implies the performance of audits by a body that is not directly involved with the management of the IG under evaluation. However, Brazilian law practically does not provide for the use of external control mechanisms, whereas in the European Union, governmental entities play a fundamental role in this process, carrying out audits and certifying the private certifiers themselves. ${ }^{25,26,31}$

According to Santos ${ }^{25}$ in Europe, where IGs have a long history, it is necessary to rethink the ways of implantation, let alone in Brazil, where this process is still very recent, as studies have shown the need for be reoriented to the construction of proposals that attend the singularities of the productive systems, mainly the alimentary ones. According to Dallabrida, Baukert and Guinzani (2020), the Geographical Indication processes must take into account a number of factors, in addition to those that typify the location, among them the product profile and the link of these products with regional conditions. And, although in conjunction with the GI promotion process, it is also necessary to develop work to enhance these products with consumers, since Brazilian products from Geographical Indications are, in general, unknown both by producers and traders and by most consumers. In this case, it is essential that the choice of the valuation of certain products by means of a GI is preceded by a broader assessment of the territories, in order to define the best strategy applicable to the achievement of this objective. ${ }^{2}$ In this context, Santos ${ }^{25}$ reinforce that local food producers, who are in fact the guardians of traditional knowledge and practices, need to be heard and respected, and to know what they can expect as a result of the implementation process. a Geographical Indication referring to its products.

\section{Geographical indication in Brazil and the potential of the state of ceará}

In Brazil, up to September 2019, a total of 73 Geographical Indications were granted by the INPI, 53 of which are Indications of Origin (IP) and 20 of Denomination of Origin (DO). However, not all the IGs granted by the INPI are in the national territory, 9 among them are located in other countries. Regarding the cheese IGs, it appears that there are already 3 PIs in Brazil and one DO located in France, but granted by INPI 2019). The total number of IG orders requested to the INPI until September 2019 was 131 IGs, 83 of which are Indications of Origin (IP) and 48 of Denomination of Origin (DO), demonstrating the interest of Brazilian producers in making IG records with a focus on their competitiveness in the national and international market. The products and services that obtained GI records cover several segments, among which the food (58\%) and beverage (17\%) segments stand out. However, Cerdan et al. ${ }^{35} \mathrm{emphasize}$ that the recognition of a GI, by itself, is not enough to guarantee a priori the commercial success of a product and, consequently, the development of the producing region. A series of variables need to be considered such as: "product characteristic and production chain, market, level of structuring of producers (social capital), distribution channels, among many others".
In the Brazilian Northeast, up to September 2019, 18 IGs were requested, being granted until 2019 14, with 12 Indications of Origin (IP) and 2 Denominations of Origin (DO) (INPI 2019). However, the Northeast has great potential for products that can receive the GI seal, both in the area of food and in the area of handicrafts. The state of Ceará has only one IG certified as Denomination of Origin (Camarão da Costa Negra), but it has significant potential for the creation of other IGs for having several products, mainly agrifood, with certain notoriety and specific characteristics that are responsible for the different flavors which present, in addition to handcrafted products with a recognized reputation, such as Queijo Coalho de Jaguaribe.

\section{Methodology}

In this study, a research of a descriptive and exploratory nature was used, based on a qualitative approach, focusing on a case study, that is, analyzing the obstacles and challenges for the implantation of the Queijo Coalho de Jaguaribe IG in Ceará. For such a study, multiple and varied sources of evidence are needed. Therefore, the techniques most used in this work were documentary research, interviews and direct observation, as recommended by ${ }^{37}$ The documentary research was carried out on documents produced by the Brazilian Agricultural Research Corporation (Embrapa), of the Brazilian Micro and Small Business Support Service (Sebrae), of the Ceará Economic Research and Strategy Institute (IPECE), of the Historical Heritage Institute and Artístico Nacional (IPHAN), from the National Institute of Industrial Property (INPI), among others. As for the interviews, they were semi-structured in order to allow the interviewees total freedom of expression when answering the questions, thus favoring the understanding of their views regarding the processes of implantation of a GI, as well as the obstacles and challenges (GODÓI ; MATTOS, 2006). The research was developed in three stages. In the first stage, documentary research was carried out with the collection of secondary data on the topic Geographical Indications and data on the production of Queijo Coalho de Jaguaribe and characterization of the region. In a second stage, interviews were carried out with public agents (City Hall, Embrapa, UECE, Sebrae, among others) and private agents (President of the Association and producers), involved in the process of implementing the IG do Queijo Coalho de Jaguaribe.

In the third stage, direct observation took place, through the participation of a Public Hearing that took place on June 27, 2019, at the Legislative Assembly of the State of Ceará, in which Bill 0087/2019 was debated and discussed on the "Production and Marketing of Artisanal Cheese and Butter in the State of Ceará", Representatives of institutions involved in the process were elected as subjects of this study, such as: a representative from Sebrae-CE, a researcher from Embrapa, a representative from the Jaguaribe City Hall; the president of the Jaguaribe Dairy and Milk Producers Association (Queijaribe) in addition to four cheese producers, who were initially selected to participate in the IG, a researcher from the State University of Ceará and a representative of the Map and a representative of the IPHAN, making a total of eleven interviews. The interviews were conducted in person, with the exception of those applied with the representative of the Map and the one of the Jaguaribe City Hall, to whom the form was sent by email. The interviews took place in the months of July, August and September 2019, and were recorded in audio and later transcribed. In the qualitative analysis of the data, the technique of content analysis was used, which, according to Bardin (2016), is characterized by trying to understand the forms of communications beyond their immediate meanings, enriching the exploratory attempt of systematic analysis of all forms of expression, formal and informal. 


\section{Results and discussions}

\section{Characteristics of the region and actions taken to recognize the geographical indication of coalho cheese from jaguaribe, ceará}

The Vale do Jaguaribe region has an estimated population of 390,693 inhabitants, according to the IBGE (apud IPECE, 2017), and is composed of 15 municipalities, with the most important being the municipalities of Russas, Morada Nova, Limoeiro do Norte, Jaguaribe and Tabuleiro do Norte, for having the highest demographic densities. The Jaguaribe Valley has the second largest dairy basin, the largest dairy cattle herd in the state, with 78,736 heads and production of 124.2 million liters of milk / year (IPECE, 2017). This dairy productivity of the Jaguaribe Valley has been highlighted in the production of Coalho Cheese with peculiar characteristics to the artisanal style, assuming great economic and social importance in the generation of employment and income in this region. There are no limits, a priori, for the size of the area to be delimited for a GI, as long as it has homogeneous characteristics and has tradition and reputation in the production of Coalho cheese. However, the use of large areas would cause logistical problems and would require a decentralized organization of management and control. For this reason, in principle, among the municipalities that make up the Jaguaribe Valley, although the vast majority of them produce this type of cheese, Embrapa has developed preliminary studies aiming at the possibility of obtaining a future GI, called Indication of Origin (IP) , of artisanal Coalho cheese (QCA) produced in the municipality of Jaguaribe-CE. CSF is understood to mean cheese made from raw and whole cow's milk, according to local tradition. Jaguaribe's CSF has become a popular delicacy in the state of Ceará and the states of Brazil, with great potential for reaching other markets. It has a centuries-old tradition and has been associated with some factors with peculiar sensory characteristics, in addition to being recognized as a typical delicacy of the Jaguaribe region. The Jaguaribe CSF represents a relevant socioeconomic, cultural and gastronomic value, whose bases are found in the history of the cattle rancher in the northeastern semiarid and in the "savoir-faire" of the cheese that is transmitted from father to son, maintaining the tradition, producing cheese from artisanal form, using the practical knowledge built through generations. ${ }^{37}$ The wisdom that has been passed down between generations currently has the support of science and technology, aiming at new technological and hygienic standards, Thus, the first cheesemakers that were included in the delimitation of the IG were those of the municipality of Jaguaribe, affiliated with the Queijaribe Association. This was one of the conditions imposed, as a mandatory requirement, by Embrapa technicians to receive the necessary support from the institutions involved in the implementation of the IG.

Embrapa technicians, taking these criteria into account, mapped the geographical delimitation of the Coijo de Jaguaribe Cheese IG, considering 15 cheese factories for the effective action of partner institutions, aiming at improving quality and searching for the Origin (IP). From the perspective of Geographical Indication (GI), for two years the Cheese Coalho de Jaguaribe was studied in its physicalchemical, sensory, biochemical and proteomic characteristics, as a way to contribute to the authenticity of the product given its geographical origin. According to data from the Association of Producers of Milk and Derivatives of Jaguaribe (Queijaribe), $88.8 \%$ of the milk produced in the municipality of Jaguaribe is intended for the production of Coalho Cheese in 66 local dairy products and the rest is for human consumption, being its production chain composed of small and medium-sized cheese companies, responsible for generating 2,500 direct and indirect jobs, with a monthly revenue of about $\mathrm{R} \$ 3$ million, obtained only from the sale of cheese. ${ }^{38}$ The geographical name of the product makes sense to consumers, since when they find or order Jaguar Coalho Cheese, it is known that it comes from a city with a traditional cheese tradition and even from a region known for its "know-how". of product. In this way, it is possible to make the name of the cheese also bring the local culture to the consumer market and that the historical factor existing in the product is disseminated. Given these facts, institutions with Embrapa, Sebrae and the State University of Ceará, in addition to the producers' association, have been trying to register the IG of Origin of Coalho Cheese from Jaguaribe since the beginning of 2009. Next, the roles of these actors in the process to understand its obstacles and challenges.

\section{The roles of the institutions involved in the IG coalho cheese from jaguaribe process, ceará}

The institutions involved in the implementation process for the registration of IG Queijo Coalho de Jaguaribe are: EMBRAPA, UECE, SEBRAE, MAPA, INPI, PMJ and the Association of Milk and Derivatives Producers - QUEIJARIBE. According to the interviews conducted with the president of Queijaribe and some producers, Embrapa Agroindustry Tropical, Sebrae and the State University of Ceará were the most active institutions in this process. EMBRAPAIt was the initiative to implement the IG of the Jaguaribe QCA with producers affiliated to the Queijaribe Association. Initially, Embrapa went into the field with the Project "Valorização do Coalho Cheese produced in the Northeast Region", more with a focus on Jaguaribe Coalho Cheese. This project had as one of its objectives the search for the Geographical Indication of Coalho Cheese from Jaguaribe, thus seeking to improve the entire production chain. In practice, any investment made would ensure the manufacture of a quality product, within the standards of sanity and defined manufacturing practices, enabling the conquest of new markets and the practice of competitive prices. In addition, Embrapa technicians analyzed hygienic-sanitary aspects of the cheesemakers involved. Embrapa also carried out microbiological analyzes, physical-chemical and sensory aspects of the cheeses and accompanied consumers from Ceará to assess the acceptance of the artisanal product. In summary, Embrapa played a fundamental role in improving the quality of cheese through training of producers and improvements in the infrastructure of cheese producers.

UECE - It also played a fundamental role through a researcher and professor at the Institution, in the implementation phase of the IG of the Jaguaribe-CE QCA. According to the interviewed researcher, one of the first actions, seeking to improve the quality of production and the recognition for the IG came through the "Projeto Bovinocultura Leiteira de Jaguaribe", which aimed to develop training, workshops and consultancy for milk and cheese producers. The UECE also played a prominent role in stimulating and supporting the IG project of the Jaguaribe CSF. In partnership with Embrapa and Sebrae, training was given to milk and cheese producers, as well as elaborated several proposals and suggestions for the Jaguaribe CSF producers, as an incentive (bonus) for milk quality; use of more appropriate equipment and utensils; improving the quality of the raw material; improved efficiency in delivering milk to cheese makers; cheesemaker training; use of good quality inputs; hygiene practice in milking; standardization of the cheese-making process; implementation of good manufacturing practices in cheese makers; adequate facilities, such as the use of a cold room; implementation of a milk and cheese quality control laboratory in Jaguaribe; product marketing; partnerships / agreement with research institutions, universities, public and private agencies; Financial support from official banks (BNB, BB, CEF) to the Jaguaribe cheese industry, among others. standardization of 
the cheese-making process; implementation of good manufacturing practices in cheese makers; adequate facilities, such as the use of a cold room; implementation of a milk and cheese quality control laboratory in Jaguaribe; product marketing; partnerships / agreement with research institutions, universities, public and private agencies; Financial support from official banks (BNB, BB, CEF) to the Jaguaribe cheese industry, among others. standardization of the cheesemaking process; implementation of good manufacturing practices in cheese makers; adequate facilities, such as the use of a cold room; implementation of a milk and cheese quality control laboratory in Jaguaribe; product marketing; partnerships / agreement with research institutions, universities, public and private agencies; Financial support from official banks (BNB, BB, CEF) to the Jaguaribe cheese industry, among others. Although most universities did not formulate public policies, they offered important support in the development of GI in the country, mainly through research projects developed under stricto sensu programs. Generally, because they are inserted in the regions covered by the projects and have researchers from various areas (facilitating interdisciplinary approaches), they have been able to offer important contributions to the strengthening of the IGs. ${ }^{2}$

SEBRAE - Through its Regional Office in Limeiro do Norte-CE, it acted and interacted with small producers in the municipalities of the Jaguaribe region for many moments. Sebrae used its work methodology in the process of implementing the IG of the Jaguaribe CSF in two phases: awareness and training, both aimed at Jaguaraguan companies and rural producers. In the awareness phase, he used publications, linking works in the media, holding events (Festival queijo Coalho de Jaguaribe), which resulted in an important contribution to popularize the concept of GI and stimulate the interest of cheese producers in Jaguaribe in recognizing the product with potential for GI. The second stage of work was the training of small businessmen and also of rural producers, with training directed to the business plan, associativism, food handling, good manufacturing practices, among others. Sebrae has entered into partnerships with the Jaguaribe City Hall (PMJ) and the Jaguaribe milk and dairy products association (Queijaribe), allowing for the promotion of various promotional events focused on cheese, such as lectures and workshops, given by specialists in the areas of milk and cheese production; the Jaguaribe Region Business Fair -FENERJ, the Jaguaribe Cheese Festival ", which is held annually. All of these actions aim to strengthen the milk production chain and give visibility to Coalho cheese from Vale do Jaguaribe-CE. Sebrae has entered into partnerships with the Jaguaribe City Hall (PMJ) and the Jaguaribe milk and dairy products association (Queijaribe), allowing for the promotion of various promotional events focused on cheese, such as lectures and workshops, given by specialists in the areas of milk and cheese production; the Jaguaribe Region Business Fair -FENERJ, the Jaguaribe Cheese Festival ", which is held annually. All of these actions aim to strengthen the milk production chain and give visibility to Coalho cheese from Vale do Jaguaribe-CE. Sebrae has entered into partnerships with the Jaguaribe City Hall (PMJ) and the Jaguaribe Milk and Dairy Productors Association (Queijaribe), allowing for various promotional events focused on cheese, such as lectures and workshops, given by specialists in the fields of milk and cheese production; the Jaguaribe Region Business Fair -FENERJ, the Jaguaribe Cheese Festival ", which is held annually. All of these actions aim to strengthen the milk production chain and give visibility to Coalho cheese from Vale do Jaguaribe-CE. taught by specialists in the areas of milk and cheese production; the Jaguaribe Region Business Fair -FENERJ, the Jaguaribe Cheese Festival ", which is held annually. All of these actions aim to strengthen the milk production chain and give visibility to Coalho cheese from Vale do Jaguaribe-CE. taught by specialists in the areas of milk and cheese production; the Jaguaribe Region Business Fair -FENERJ, the Jaguaribe Cheese Festival ", which is held annually. All of these actions aim to strengthen the milk production chain and give visibility to Coalho cheese from Vale do Jaguaribe-CE.

Although the institution plays an important role in strengthening GI in Brazil, its work methodology has some limitations. Generally, their actions, in the form of consultancies and advisory services, often with determined deadlines, end up prioritizing the preparation and deposit of the IG recognition project at the INPI. Another point is related to the fact that the excessive focus on the market ends up privileging the economic dimension of the IGs, leading them to see only one business in them (PELLIN, 2019). QUEIJARIBE - Associação was founded on May 29, 2005 and its main objective is to strengthen, through associativism, the activity of cheese and milk producers in the Jaguaribe region, Ceará. Therefore, it is up to the Association to encourage the collective interest of aggregation, cooperation and integration of members, in order to strengthen their representativeness, because according to the INPI, to receive the grant of a Geographical Indication for food products, applicants must have a association or cooperative society. In fact, the Association was born out of the need for producers of milk and dairy products in Jaguaribe to join forces to bargain for better values when buying inputs and selling products (milk and cheese). According to the current President of Queijaribe: "Until recently, the point was reached that the association could not sell or buy, because it simply did not have the National Register of Legal Entities (CNPJ), as there is a law that did not allow an association to trade without CNPJ. What did this bring to the association? The associates started to negotiate with their own names, because they could not use the name of the association and, as a result of this impasse, there was a great stampede of associates and, consequently, in the weakening of the association, having today only 15 associates ". According to him, the Bill ( $\left.\mathrm{PLn}^{\circ} 0087 / 2019\right)$ that regulates the production and marketing of artisanal cheeses and butters in the state of Ceará, which is being processed by the Legislative Assembly of Ceará, will strengthen the association, and everything will be easier, like the search for financing and partnerships.

According to the Embrapa researchers, the work carried out by them (researchers) and by other partner institutions, such as Sebrae and Uece, aiming at the construction of the Geographical Indication (IG) for Coalho Cheese from the Jaguaribana region, was incessant and promising. . The data collected through the mapping of cheesemakers with GI potential, the product description, with the entire production flowchart of artisanal Coalho cheese from the Jaguaribe region, and the research to differentiate the cheese were realized in requirements for service to the construction of the IG, since this cheese has tradition and its association by consumers with some sensory characteristics, the shape and other peculiarities differentiate it from those produced in other states in the Northeast. Finally, it is also important to highlight the role of Uece, which has made and continues to make important contributions to the strengthening of discussions about the implantation of GI with regard to Coalho Cheese from Jaguaribe through its researcher, who has shown / demonstrates great scientific interest in the theme, as well as stimulating the development of research projects that address themes related to GI and their contributions to the development of the regions where they are located.

\section{Main obstacles and challenges to the implantation process of the coijo queijo IG}

\section{Main obstacles}

One of the most cited obstacles in the literature is the difficulty in convincing producers to accept obtaining GI. According to Thaines 
and Meleu (2013), in this case, it is necessary to carry out a work of awareness to convince producers, instilling in them the idea that the Geographical Indication can be an interesting instrument for the local development of the region and for the product, in reason of the differential that adds value compared to the others produced in the region. In the case of cheese producers from Vale do Jaguaribe, this fact did not necessarily constitute an obstacle, in view of the previous question to which they were submitted on the acceptance or not of this project for the implementation of the IG of the Jaguaribe QCA, manifesting itself if very favorable, according to the Embrapa Researcher interviewed: [...] the acceptance was very good because their idea of GI was correct, but we had to gothrough many challenges for us to have this and what we said to them: people, Embrapa is here .. Sebrae, Uece and Nutec are here to guide the path you have to take to apply for certification, and if something is missing you will not be able to do it because none of these institutions can ask for IG and you have to be prepared for that, but the acceptance was good. (Researcher at Embrapa, 2019). It can be seen in this testimony that the Researcher drew the producers' attention to the fact that the request or request for the registration of IG could only be made by them, through the Association, and that the Institutions involved had only the role of advisors in the search for certification and, subsequently, the registration of Geographical Indication. According to the Embrapa Researcher, the main obstacle identified that as it prevented the progress of the IG of the Jaguaribe CSF was the absence of specific legislation for the regulation of the manufacture of artisanal cheeses, which resulted in the request for registration of the cheese being blocked Jaguaribe by MAPA, through the Superintendency of the State of Ceará, she emphasizes that: Well, I will tell you the main thing and one of the only obstacles that we have seen so far, and that is why we have not taken the process forward: legislation. The state of Ceará has no legislation for artisanal cheeses. When we went to propose the documentation to file the GI request, we were already barred, because how are we going to do it ... the Ministry of Agriculture, has no legislation that accepts raw milk products. [I asked if until today there was no such legislation] ... until today, June 12, 2019, there is no such legislation. (Researcher at Embrapa, 2019).

The Embrapa Researcher also pointed out that several meetings were held with the agencies (Map and Agricultural Defense Agency of the State of Ceará - Adagri) responsible for the legislation and emphasized that the biggest problem is in the use of raw milk for cheese production, and that these inspection institutions would only accept the production of cheese with raw milk if it was matured for at least 60 days, according to the conditions recommended by the current legislation (Decree $\mathrm{n}^{\mathrm{o}}$ 9,013, of March 29, 2017) , $^{24}$, alleging maintain microbiological safety and product quality. However, cheese producers in Jaguaribe do not do this procedure. The publication of the recent Law No. 13,680, of June 14, 2018, ${ }^{39}$ stands out, which deals with the inspection of products and foods of animal origin produced by hand. This law definitively recognized the theme and created the Arte Stamp, which started to identify artisanal products, and on July 18, 2019, Federal Decree $n^{\circ} 9.918$ / $2019^{39}$ regulating the use of the Arte Stamp was published, which will allow the sale of artisanal products throughout Brazil even if they have been inspected only by the Municipal Inspection Service (SIM) or by the State Inspection Service (SIE). However, the technical standards for processing these products are not detailed. But there is still a lot to do, the changes in legislation in general have been focused on general aspects, and the term artisanal does not yet have a clear concept necessary to support the regulation. According to Santana (2011), failure to comply with the standards required by health surveillance are factors that hinder the development of artisanal cheese production, which is restricted to its production area and cannot reach other markets. The Embrapa Researcher also reported that the Sanitary Inspection Seal (SIE), at the time, even agreed to have raw milk products, only that they also required a maturation time of 22 (twenty-two) days, a procedure that the majority of cheese makers in Jaguaribe and practically the whole of Ceará do not do it, that is, they do not obey and do not meet the time required for maturation until today, as they make cheese one day and the next is already on the market.The Embrapa researcher also reported that "the State Inspection Seal -SIE, at the time, even agreed to have raw milk products, only that ADAGRI also required that there be a minimum maturation time of 22 (twenty-two) days, a procedure that most cheese producers in Jaguaribe and all of Ceará do not do, that is, they do not have the tradition of maturing cheese, as they produce cheese one day and the next is already on the market".

The Embrapa researcher also reported that there was great resistance to changes on the part of some milk and cheese producers in the region, as they welcomed the guidelines for adopting and adapting to Good Manufacturing Practices (GMP). This would be the first step to be taken to register producers, so only cheesemakers affiliated with Queijaribe were able to participate in various actions in the process of recognizing the IG of the Jaguaribe QCA. In this case, the adoption of GMP has, in a way, become an obstacle to the implementation of the IG. In this sense, Almeida et al. ${ }^{40}$ highlight the conflicts between specialized technicians and a traditional / non-specialized sector for the adoption of specific techniques for food security The UECE researcher highlights the lack of associativism as the main obstacle to the implementation of the IG of the Jagauaribe-CE: is that there, for example, in Jaguaribe, there is a lot of political interference, so this is bad because politics interferes within the Association and then it starts to fragment the Association ". (Researcher at UECE, 2019). This fact corroborates with what Tahim and Araújo Júnior ${ }^{20}$ and Niederle ${ }^{29}$ affirm regarding the obstacles pointed out by them in their studies, such as the weak association, the low degree of organization of producers and the non involvement of all producers in the association.

The second major obstacle for this researcher at UECE is the lack of motivation of producers to want to carry out the time-consuming process of the Jaguaribe CSF, and the third is accommodation and they do not have a vision for the future. For the researcher, the producers are very accommodated, as they know that even in the informal sector, the sale of their cheese is already guaranteed, at least most of them. So, they don't worry about improving to get a GI, because their cheese is so recognized, so sought after, that even in hiding they sell everything. However, according to Santos ${ }^{32}$, informality is an unfavorable situation, because, even though they continue to market their product, they are subject to apprehensions, face restrictions to increase their production and the prices earned for the product are significantly lower. For the Sebrae representative, the biggest obstacles are in the requirements of the legislation and in the low investment capacity of the artisanal producer to adapt to the current legislation.

This obstacle was quite evident, during the public hearing held in the Auditorium of the Legislative Assembly of Ceará, on June 27,2019 . In this public hearing, the issue of the low capacity of the producer to invest and adapt to the current rules became very evident. . Most of the producers interviewed in this survey complained about the lack of financial conditions to improve their physical facilities and thus meeting the requirements of current legislation. This fact corroborates what the studies of Pellin ${ }^{2}$ and Niederle ${ }^{3}$, who highlight the high cost of the process of recognition of a GI in Brazil and the lack of financial support from the State for GI, mainly in the postrecognition stage. In the opinion of the president of Queijaribe, the main obstacle to the implementation of the IG of the Jaguaribe CSF 
is the lack of state legislation to regulate the manufacture of artisanal cheeses, because without legal support, funding cannot be obtained. For cheese producer A, the main obstacle lies in the political issue: $[\ldots]$ the politicians do not let things happen as they have to, as they are positioning themselves stronger than the producer himself. They (the politicians) fight more for the vote than for the producer's desires, and this has always been observed. The lack of legislation itself is a political issue, because if they (the politicians) wanted this law, it would have already advanced, it would have already left the paper and we would have already left the underground and would already be working honestly without having to deviate from the route, hiding so as not to get caught with his production (Produtor A de Queijo Coalho de Jaguaribe, 2019).In this context, Silva et al. ${ }^{27}$ also highlighted in their study the game of political and economic power between local producers, politicians and landowners as being a major bottleneck in the implementation of GI.

For the Technician of the Municipality of Jaguaribe, the bigges obstacle is the formation on the process of creation of the Geographical Indication area, with the cheese producers of the municipality. The Mayor of the city of Jaguaribe, on the other hand, considers the absence of legislation as a major obstacle to the implementation of the IG, corroborating the speech of other interviewees when he emphasizes that "the state of Ceará owes this legislation to cheese producers and [...] that almost all the states in the Northeast already have the law that protects and regulates the production and commercialization of artisanal cheese ". He added that "the drafting of the law is also a form of respect for consumers, who are consuming cheese whose origin and mode of transport are unknown". According to the Mayor, Another important obstacle to be highlighted in this study was that part of a group of interviewed producers (seven producers) said that they still do not know well understood what this IG can actually improve their lives, observing that the advantages of obtaining a GI seal is not very clear to some of them, although they all agree with the GI registration process. It is also perceived in the words of these producers a great desire for the authorities to continue the process of seeking recognition for the IG of Queijo Coalho, according to them, which started in 2011, and which has not yet been implemented. In their reports they also highlight the great need for qualifying producers through training, so that they can have quality raw material.

The speech of an artisanal cheese producer identifies and also highlights the importance of the group's movements towards conquering the market, of an appropriate market for artisanal products. And in addition to what was said by the producer, two interlocking issues were identified that permeate the narrative and the actions of the group of public agents that gave / set the tone for the Jaguar farmers' cheese meanings: the first regarding the implementation of physical, legislative and techniques focused on what the agents called / call "Good Manufacturing Practices (GMP)" - as an irreplaceable element for the maintenance of cheese makers in the consumer market; When it is said that a product or service is notorious, it means that it causes recognition, remembrance and spontaneous evocation, in such a way that it is distinguished from similar and similar ones. Recognition is the first step towards reaching a basic level of notoriety. Notoriety has to do with the high degree of knowledge by the specific consumer public, with values transmitted due to intrinsic or specific characteristics of that product or service. The quality of Jaguaribe Coalho Cheese is well known and its notoriety and reputation is proven in research, books, articles, dissertations, theses, links to television reports, among other records, as can be seen in the testimony of Cheese Producer B. I was in Torino, Italy, taking the cheese ... "trafficking" ... [laughs] because when I went to travel the guy asked me: can you take this cheese? And I replied: boy it is a traffic, but it's cool ... and I was baking this cheese there and I passed this cheese on the plate in Torino ... and when that cheese smelled a lot of people "came" close and "said ":" I remembered Ceará "[the Italians] ... people for the love of God is one thing ... it's a story ... the Jaguaribe cheese is a story ... the cheese from Ceará is a story and you they want to disrupt our life ... the life of the country man. Survival in the countryside is difficult ... only those who have courage are there. ${ }^{9}$

\section{Main challenges}

As for the challenges, it can be seen from the interviews that several of them need to be faced for the implantation of the Jaguaribe cheese GI, according to the reports of the interviewees below. The Embrapa Researcher pointed out as the main challenge to the implementation of the Geographical Indication (GI) of Coalho de Jaguaribe Cheese, the awareness of the producer to follow the norms contained in the Good Manufacturing Practices (GMP). According to the Researcher:Producers have been working with the tradition of family know-how for several generations and, because of this, they do not welcome the question of maturation, which is the process of physical-chemical, microbiological and sensory transformations that occur with cheese along the way. over a period of time, under certain conditions of temperature and humidity. ${ }^{1}$

According to Cavalcante, Bastos and Fontenele ${ }^{38}$ the maturation of the cheese is a very important stage in cheese making, in which the development of the characteristics of the cheese produced occurs. For the Embrapa Researcher, it is not a question of resistance on their part, but rather a lack of flexibility and awareness among producers about the need to adapt to good manufacturing practices. Santos ${ }^{32}$ clarifies that the empirical evidence allows us to say that traditional food products are subject to two states: one that protects, safeguards and values; another who pursues, apprehends and condemns. The first was represented mainly by the support for actions to safeguard and protect assets, developed by state institutions with the support and coordination with civil society organizations. In this field of state action, notions such as those of culture and heritage are intertwined and become relevant to be triggered. The cheesemakers took the milk to make the cheese from various, diverse suppliers ... I myself followed their route ... they took 2 liters of one, 3 liters of another without knowing the origin ... already in other states the production (supply) of a place just to make the cheese ... so if the cheesemaker arrived with his truck and asked: put 10 liters here ... put here 8 liters, put here so many liters ... that's Adagri did not accept. ${ }^{1}$

For the Researcher, the big challenge is that they had / have to have a centralized milk production or supply, thereby avoiding problems arising from the origin of the raw material, because if the cheesemaker took / takes milk from the entire region and if a problem no one will know the origin of the milk that gave rise to the problem, that is, there is no way to trace the milk. In addition, the herd had / must have a guarantee of health status, and control of foot-and-mouth disease and brucellosis, so it becomes a big and complex challenge. With regard to quality certification via Geographical Indications, some aspects need to be evaluated, including the concept of quality itself. In traditional food circuits, as opposed to what happens today in global forms of supply, there is an intimate relationship between producers and consumers. Often, they are people who know each other and who share classification systems regarding the quality of products. So, for the Researcher, it is crucial to identify the origin of the raw material by means of a milk collection center, which carries out quick, previous control analyzes, and only afterwards sends it to Queijaribe. In addition, there is also the challenge of the question of 
the delimitation of the area, because according to the Researcher, there were cheesemakers from various places outside the limits of the municipality of Jaguaribe who wanted to be part of the IG, which is why the criterion of being associated with Queijaribe it had to be mandatory. Niederle ${ }^{3}$ also considers as a challenge of great complexity the demarcation of geographical areas for goods whose production is dispersed in the territory or spread over a wide area, even with discontinuity, as is the case of Queijo Coalho do Vale do Jaguaribe.

One of the Uece researchers interviewed pointed out as the main challenge the exit of illegality, arguing that informality is not beneficial either for the state or for cheese producers. He also stressed the importance of the Bill that provides for the production and commercialization of artisanal cheeses and butter in progress at the Legislative Assembly of Ceará, whose approval and consequent transformation into law will remedy this situation. Another great challenge pointed out by the Researcher is the need to do serious work with regard to the dissemination of basic and necessary information to consumers so that they know what artisanal cheese is, what is its value and its representativeness for the municipality and also for the state of Ceará, as it is essential to inform the population about the health benefits of artisanal cheese made from raw milk. This is also corroborated by the Representative of the City Hall. The aforementioned researcher also points out that the adaptation to GMP and the constant search for improving the quality of the raw material, in this case raw milk, is also an immeasurable challenge. The Sebrae Representative pointed out that the challenge was to raise awareness among cheese producers, partners and public institutions for the integration of efforts, in addition to technical knowledge and financial resources so that the process of implementing the Geographical Indication of Coalho Cheese from Jaguaribe really does advance. In this perspective, Pellin ${ }^{31}$ emphasize the importance of structuring an efficient institutional arrangement with the articulation of all the actors involved, being for them one of the main challenges for the implementation of Geographical Indications in the Country.

For the President of the Association of Producers of Milk and Derivatives of Jaguaribe (Queijaribe), the great challenge will be to get cheese producers to join. According to him, one of the great obstacles to the development of the Jaguaribe region is the lack of a culture of association, as "each one only wants to work individually, and a large part of the producers still do not have this awareness and that makes it very difficult". The President of Queijaribe also stressed that this is a great challenge, "because we have to show that together we are stronger". According to the President of Queijaribe, the law that will regulate the production and marketing of artisanal cheeses and butters will strengthen the Association, and everything will be easier, such as the search for financing and partnerships, For the Cheese Producer A the biggest challenge is to always be looking for improvements, that is, innovation for your own business, in his case for your own dairy. He stressed that he always "seeks to be on an equal footing in competitiveness without fearing the big businessman (the big dairy), who, always wants to overthrow the little one". The Producer also said that he is always attentive to what the cheese market can offer him. It can be seen that this artisanal cheese producer has a different view of the market from that presented by the majority of cheesemakers interviewed informally, as he spoke a lot about innovation, adding value to his product and that he is always attentive to the news related to his business, to the your product.

\section{Final considerations}

Several institutions have endeavored to standardize and standardize the production of Coalho Cheese for the implantation of the Coalho Cheese IG from Jaguaribe-CE. Among these institutions, Embrapa stands out as the main partner, the Municipality of Jaguaribe, UECE and SEBRAE as institutions that played a fundamental role in the process of raising awareness among producers. Among the actions carried out, the training / qualification of producers, workshops, consultancies, technical monitoring of the physical installations of artisanal cheese makers, technical guidance to producers and visits by health surveillance with the aim of preparing them for the recognition of GI stand out. Embrapa was the institution that was most involved in the process, including conducting research such as microbiological analysis, However, in spite of all the efforts of the institutions to create a favorable environment for the implantation of the IG of artisanal coalho cheese from Jaguaribe in Ceará, it was observed that the process of implantation of the IG was not able to advance due to several obstacles, being the most striking of them the non-existence of specific legislation on the production and marketing of artisanal cheeses in the state of Ceará. This means that there was a lack of articulation between the institutions involved in the process, because without adequate legislation for the production of cheese in the Jaguaribe region, registration of the IG became impossible.

As for the challenges, the main one is the absence of specific legislation aimed at the production and commercialization of artisanal cheese in the state of Ceará, followed by the adaptation of artisanal cheese makers to the requirements for obtaining the SIE and SIF. Other challenges were the lack of funding and greater mobilization, awareness and motivation of the actors involved in the process; lack of articulation between the producers' association with other sectors and actors; the definition of its strategies; the lack of recognition and appreciation of territorial resources by the community and government agencies, among others. In summary, obtaining a GI is a complex and expensive process that requires strong and integrated institutional arrangements, covering multiple and interdisciplinary activities of the actors involved.

\section{Acknowledgments}

None.

\section{Conflicts of interest}

The author declares there is no conflict of interest.

\section{References}

1. Lima MAC. Technical subsidies for the geographical indication of origin of the Vale do Submédio São Francisco: table grape and mango. Petrolina-PE: Embrapa Semiárido, 2009.

2. Pellin V. Geographical indications and regional development in Brazil: the performance of the main actors and their methodologies of work. Interaces (Campo Grande). 2019;20(1):63-78.

3. Nierdele PA, Vitrolles D. Geographical indications and qualification in the Brazilian wine sector. Society and Agriculture Studies. 2010;18(1):5-55.

4. Pellin V, Vieira ACP. Geographical indications in Brazil: a postregistration perspective. In: Locatelli L (org.). Geographical indications. challenges and perspectives in the 20 years of the Industrial Property Law. Rio de Janeiro: Lumen Juris. 2016;89-112.

5. Mascarenhas G, Wilkinson J. Geographical indications in developing countries: potential and challenges. Agricultural Policy Review. 2014;23(2):103-115.

6. Anjos FS, Silva FN, Caldas NV. Geographical indications, social capital and territorial development. Redes (St. Cruz Sul, Online). 2020;25(2):721743.

7. Rezende AA, Marcelo SS, Daniel LP. Geographical indication a way for economic growth for Nazaré das Farinhas and Maragogipinho, Bahia. Paranaense Magazine of Development, Curitiba. 2017;38(132):55-76. 
8. Goncalves AS, Almeida BA. IN;. S. Panorama of geographical indications in Brazil. Economic Development Magazine - RDE, Salvador, BA. 2018;3(41):130-144

9. Omab O. Research and development actions to recognize the Geographical Indication of Coalho Cheese from Jaguaribe-Ce. In: NATIONAL DAIRY CONGRESS, 26., 2009, Juiz de Fora. Annals [...]. Juiz de Fora: Cândido Tostes Dairy Institute, 2009.

10. Giovannucci D. The new 'local': linking geographical indications and organics. Geneva: Luiz International Trade Center, 2008.

11. Hayes DJ, Lence SH, Stoppa A. Farmer-owned brands? Iowa: Iowa State University, 2003.

12. Dutra D. Mcoffee in Minas Gerais: evolution and perspectives in the view of its managers. 2009. $166 \mathrm{f}$. Dissertation (Master in Administration) Federal University of Lavras, Lavras, 2009.

13. Vellso CQ. Geographical indication and sustainable territorial development: the role of social actors in the dynamics of territorial development from the connection of the product to the territory (a case study in Urussanga, SC). 2008. 166 f. Dissertation (Master in Agrosystems)-Federal University of Santa Catarina, Santa Catarina, 2008

14. Vieira ACP, Brich KL (org.). Geographical indication, collective signs and development. São Paulo: IBPI, 2015.

15. Martins ISS, Vasconcellos AG. The Relationship between the Regulation for the Use of Geographical Indications and traditional knowledge: the case of guaraná involving the territories of Maués and the Indigenous Land. Prospecting Notebooks - Salvador. 2020;13(1):293-308.

16. Gollo SS, Castro AWV de. Geographical indications in Brazil: indications of provenances already granted and areas and products with potential for certification. In: Brazilian congress of economy,administration and rural sociology. July 20 to 23, 2008. Proceedings [...]. Rio Branco-Acre: UFAC, 2008 .

17. Caldas NV. Comparative study between certification systems for organic products in the context of Brazilian and Spanish family farming. 2011. $208 \mathrm{f}$. Thesis (Doctorate in Agricultural Sciences)-Federal University of Pelotas, Pelotas, 2011.

18. Vieira ACP, Watanabe M, Bruch KL. Perspectives on the development of vitiviniculture in the face of the recognition of the Indication of Origin Valleys of the Goethe Grape. Management, Innovation and Technologies Magazine, São Cristóvão, SE. 2012;2(4):327-329.

19. Dallabrida VR, Baukart KS, Guinzani W. Territorial signs and geographical indication: an evaluation of experiences with the application of methodological instrumental. Interactions Campo Grande. 2020;21(1):195-211.

20. Tahim EF, Araujo Junior IF. Geographical indications as a factor of competitiveness and sustainability for local productive arrangements. the case of IG da Costa Negra in Ceará. In: Congress of the braxilian society of economy, administartion and rural sociology. Vitória. Annals [...]. Victory: Sober, 2012

21. Niederle PA, Mascarenhas GC, wilkinson MJ. Governance and institutionalization of geographical indications in Brazil. RESR. 2017; 55(1): 85-102.

22. Froehlich JM. The experiences of geographical indications in southern Brazil and family farming. In: Froehlich JM editor. Territorial Development: production, identity and consumption. Ijuí: EdUnijuí, 2012.

23. Sá ASC. Legislation and programs for the development of geographical indications in Brazil. Prospecting Notebooks, Salvador. 2019;12(3):706716.

24. Brazil. Ministry of Economy. National Institute of Industrial Property. Normative Instruction No. 25, of August 21, 2013. Establishes the conditions for the registration of geographical indications. 2013
25. Santos JS, Menasche R. Valuation of traditional food products: the uses of geographical indications in the Brazilian context. Cuad. Spitting Rural Bogotá. 2015;12(75):11-31.

26. Silva IRC da. Cassava flour know-how: tradition in the production process, in Nazaré-BA. Prospecting Notebooks. 2015;8(2):365-374.

27. Silva FN da, ANJOS Flávio Sacco dos, CALDAS Nádia Velleda, et al Challenges to the Institutionalization of Geographical Indications in Brazil. Regional Development Magazine in debate. 2012;2(2):31-44.

28. Wilkinson J, Cerdan C, Dorigon C. Geographical Indications and "origin" product in Brazil: the interplay of institutions and networks. World Development. 2017;98:82-92.

29. Niederle PA. Commitments to quality: geographic indication projects for wines in Brazil and France. 2011. 263 f. Thesis (Doctorate in Social Sciences) - Federal Rural University of Rio de Janeiro, Rio de Janeiro. 2011.

30. Thaines AH, Meleu M. Geographical indication as a development tool: a case study in Vale dos Vinhedos / RS. In: ASSAFIM, JM de L .; MORO, MCF (coord.). Intellectual property. Florianópolis: Funjab. 2013;214 234.

31. Pellin V, Silva LF. Geographical indications: a strategy for rural territorial development. In: International seminar on national development, 7, 2015, Santa Catarina. Annals [...]. Santa Catarina: Unisc, 2015.

32. Santos JS. Dilemmas and challenges in the valuation of traditional food products in Brazil: a study based on Queijo do Serro, in Minas Gerais, and Queijo Serrano, in Rio Grande do Sul. Pelotas: Ed. UFPel, (Ciências Agrárias Graduate). 2017. p. 5.

33. Vieira ACP. Regional development and geographical indications of coffee in Brazil: post-registration perspectives. In: Vieira ACP, et al. editors. Geographical Indications, Collective Signs and Local / Regional Development. Erechim: Deviant. 2019:169-198.

34. Valente MER. The process of recognizing the Geographical Indications of Brazilian Food and Beverages: Use Regulations, Area Delimitation and Product Differentiation. Rural Science. 2013;43(7):1330-1336.

35. Cerdan CMT. Geographical indication of agricultural products: historical and current importance. In: Pimentel LO, editor. Course on intellectua property and innovation in agribusiness. Module II. 4. edn. Florianópolis, SC: Funjab. 2014; p. 415.

36. Yin RK. Case study: planning and methods. 5. edn. Porto Alegre: Bookman, 2015.

37. $R$ Public and private actions in the implantation and development of the geographical indication of Dantas DS, Microbiological quality of rennet cheese marketed in the municipality of Patos, PB. 2012. $80 \mathrm{f}$. Dissertation (Master in Zootechnics) - Federal University of Campina Grande, Campina Grande, 2012

38. Cavalcante JFM, Bastos M, Do SR. Artisanal rennet cheese in the state of Ceará. In: Cavalcante JFM edito. Artisanal coalho cheese from northeastern Brazil. Fortaleza: Banco do Nordeste do Brasil, 2017;35-78.

39. Brazil. Ministry of Economy. National Institute of Industrial Property. INPI grants registration of geographical indication to Pirenópolis. 2019. Accessed on: 15 nov. 2019.

40. Almeida VM. Geographic identification for São Bento cheese as a territorial development strategy for the microregion of the Baixada Maranhão. Cad Prospec. 2015;8(4):808-816.

41. Godói CK, Mattos PLCL. Qualitative interview: research instrument and dialogical event. In: Godói $\mathrm{CK}$ editor. Qualitative research in organizational studies: paradigms, strategies and methods. São Paulo: Saraiva. 2006:301-324. 